\title{
Vertical stratification and effect of petiole and dry leaf size on arthropod feeding guilds in Cecropia pachystachya (Urticaceae)
}

\author{
Novais, SMA. ${ }^{a *}$, Alvarenga, AS. ${ }^{a}$, Falcão, LAD. ${ }^{b}$ and Neves, FS. ${ }^{a}$

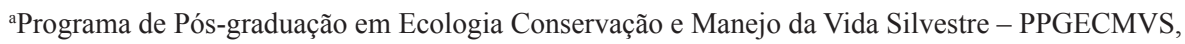 \\ Laboratório de Ecologia de Insetos - LEI, Departamento de Biologia Geral, Universidade Federal de Minas Gerais - \\ UFMG, Avenida Presidente Antônio Carlos, 6627, Pampulha, CEP 31270-901, Belo Horizonte, MG, Brazil

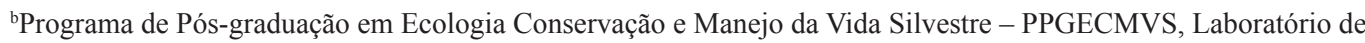 \\ Ecologia e Conservação - LEC, Departamento de Biologia Geral, Universidade Federal de Minas Gerais - UFMG, \\ Avenida Presidente Antônio Carlos, 6627, Pampulha, CEP 31270-901, Belo Horizonte, MG, Brazil \\ *e-mail: snovaisbio@gmail.com
}

Received: August 30, 2013 - Accepted: April 30, 2014 - Distributed: August 31, 2015

(With 2 figures)

\begin{abstract}
This study aimed to test for vertical stratification and the effects of dry leaf size on herbivore and predator arthropods and petiole length on insect borers in Cecropia pachystachya. The leaves were sampled in three strata: attached to the plant, suspended on the vegetation and on the ground. We detected vertical stratification only in the guild of predator arthropods associated with dry leaves, with lower richness and abundance in the attached stratum. In addition, larger leaves positively affected the insect herbivore fauna, whereas the richness and abundance of insect borers increased with petiole length. The greater isolation of leaves attached to trees relative to the surrounding vegetation likely creates greater difficulty for dispersal and colonization by non-winged predators such as spiders. Larger dry leaves provide more shelter against predators and climate variations for insect herbivores. Moreover, larger petioles increase the availability of resources and nesting sites for insect borers. These results are consistent with other studies that found a similarity in the structure of feeding guilds across vertical strata and with studies that showed an increase in species richness and abundance of free-feeding insect herbivores with increasing structural complexity of their host.
\end{abstract}

Keywords: insect herbivores, bark beetles, predators, habitat complexity, resource availability.

\section{Estratificação vertical e efeito do tamanho de pecíolos e folhas secas de Cecropia pachystachya sobre guildas alimentares de artrópodes (Urticaceae)}

\section{Resumo}

Os objetivos do presente trabalho foram testar as hipóteses de que existe estratificação vertical e efeito do tamanho de folhas secas de Cecropia pachystachya sobre artrópodes herbívoros e predadores, e efeito do tamanho dos pecíolos sobre insetos brocadores. As folhas foram amostradas em três estratos: presas à planta, caídas sobre a vegetação e no solo. Foi verificada estratificação vertical apenas para os artrópodes predadores, com menor riqueza e abundância no estrato presa. Além disso, folhas maiores afetam positivamente a fauna de insetos herbívoros, enquanto que a riqueza e abundância de brocadores aumentam com o tamanho do pecíolo. O maior isolamento das folhas presas em relação à vegetação do entorno provavelmente determina maior dificuldade de dispersão e colonização por predadores não alados, como aranhas. Folhas secas maiores oferecem maiores áreas de refúgio e abrigo contra predadores e variações climáticas para insetos herbívoros. Além disso, maiores pecíolos aumentam a disponibilidade de alimento e locais para nidificação dos insetos brocadores. Estes resultados são consistentes com estudos que encontraram uma similaridade na estrutura de guildas alimentares entre estratos verticais. Corroboram também estudos que mostram o aumento da riqueza e abundância de insetos herbívoros de vida livre com o aumento da complexidade estrutural do hospedeiro.

Palavras-chave: insetos herbívoros, brocadores, predadores, complexidade do habitat, disponibilidade de recurso.

\section{Introduction}

Tropical forests provide a wide variety of habitats and resources distributed across vertical strata (Basset et al., 2003). Arthropod diversity usually shows a clear stratification and decreases from the canopy to lower strata (Longino and Nadkarni, 1990; Basset et al., 1992, 2001, 2003; Stork and Grimbacher, 2006; Schroeder et al., 2009; Davis et al., 2011). 
The stratification of organisms is determined by resource quantity and quality, microclimate conditions, and the pressure of interactions such as predation (DeVries et al., 1999; Basset et al., 2001, 2003; Stork and Grimbacher, 2006; Brehm, 2007). However, few studies have investigated whether patterns at the species level are reflected in the vertical stratification of feeding guilds, which may be more informative regarding the functional role of arthropods in tropical forests (Grimbacher and Stork, 2007).

Vegetation structure is an important factor in determining diversity patterns of associated arthropods (Strong et al., 1984). However, different mechanisms determine species diversity at different spatial scales (Godfray and Lawton, 2001; Storch and Gaston, 2004). Due to the small size and relatively sessile behavior of many arthropod species, small variations in host structure can have a major impact on foraging efficiency (Price et al., 1980). In addition to foraging sites, these organisms can use vegetation microhabitats as oviposition and nesting sites, and for shelter against temperature and humidity fluctuations and protection against natural enemies (Lawton, 1983; Halaj et al., 2000a, b; Basset et al., 2003).

The diversity of herbivorous insects generally increases with the structural complexity of their host (Lawton, 1983; Campos et al., 2006; Espírito-Santo et al., 2007; Neves et al., 2013). This effect is also observed in their natural enemies (Halaj et al., 2000a, b; Ribas et al., 2003; Sperber et al., 2004; Sanders et al., 2008), even though some studies have failed to find this relationship (Riihimaki et al., 2005; 2006; Vehvilainen et al., 2008). Conversely, even though the diversity of natural enemies increase, large plants can provide herbivores with more enemy-free space due to their size and architectural complexity (Lawton, 1983; Jeffries and Lawton, 1984; Heisswolf et al., 2005; Obermaier et al., 2008).

The Neotropical genus Cecropia (Urticaceae) comprises widely distributed trees in the Brazilian flora. The genus consists of pioneer trees typical of secondary formations or forest gaps that are easily recognized by their palmately lobed leaves and spathes enclosing parts of the inflorescence (Romaniuc Neto et al., 2009). The Cecropia leaves, depending on the plant size and architecture, reach differing sizes, with petioles varying from 30-80 cm in length (Romaniuc Neto et al., 2009). Therefore, its leaves have a large leaf surface and, when they dry, acquire the wrinkled appearance with a large number of cameras and spaces between the folds of their leaves, providing an important resource that is used by a variety of arthropod species (Rosenberg, 1990; Servat, 1995). Furthermore, the older Cecropia leaves dry while still attached to the tree and, after some time, fall directly on the ground or accumulate on the aboveground vegetation. The petioles are relatively long and their diameter enables colonization by some insect groups, especially beetles in the subfamilies Scolytinae, Curculionidae, and occasionally Cerambycidae (Jordal and Kirkendall, 1998; Weng et al., 2007).
In general, little is known about the distribution patterns of arthropods associated with dry leaves and the mechanisms that determine these patterns. Thus, this study aimed to test the following hypotheses: i. there is vertical stratification in the herbivore and predator arthropod guilds associated with dry leaves and in bark beetles associated with petioles of Cecropia pachystachya; since the fallen dry leaves have probably more chance to be colonized by arthropod due to the greater complexity and heterogeneity of the surrounding environment. ii. the richness and abundance of herbivore and predator arthropods and insect borers are positively influenced by dry leaf size and petiole length, respectively; since the largest physical structure of largest dry leaves and petioles probably determine a greater availability of resources, space for herbivores and predators and food for insect borers.

\section{Material and Methods}

\subsection{Study area}

The study was conducted in the Rio Doce State Park (PERD), the largest Atlantic forest remnant in the state of Minas Gerais, Brazil. The park encompasses part of the municipalities of Timóteo, Marliéria, and Dionísio, and has an area of approximately 37,000 ha

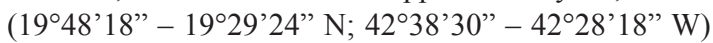
(IEF, 2012). Temperature in the park ranges from 28 to $39^{\circ} \mathrm{C}$ in the summer and from 7 to $20^{\circ} \mathrm{C}$ in colder and drier months, whereas annual precipitation ranges from 1350-1900 mm (Feio et al., 1998).

\subsection{Sampling design}

Thirty-six C. pachystachya individuals were selected along a transect of approximately $1.5 \mathrm{~km}$, from which 138 dry leaves were collected in three strata: attached to the tree (attached, $\mathrm{n}=31$ ), suspended in arboreal vegetation (vegetation, $\mathrm{n}=53$ ), and lying on the ground (soil, $n=54$ ). The number of samples in each stratum was determined according to the availability and accessibility of leaves, and a maximum of three leaves were sampled per stratum in each individual. Each leaf was placed in a sealed plastic bag to prevent the loss of species. Petiole length was measured in the laboratory using a tape measure and used as an indirect measure of leaf size and resource for insect borers.

\subsection{Sampling of arthropods}

The petioles were sorted thoroughly and the leaves were swept with a fine brush to remove associated organisms for subsequent identification. The arthropods were stored in $70 \%$ alcohol, sorted to family level and morphotyped (Borror et al., 2002). Next, the richness (number of morphospecies) and abundance of herbivores and predators per leaf and borers per petiole were determined. All arthropods sampled were deposited in the collection of the Laboratory of Insect Ecology, Federal University of Minas Gerais. 


\subsection{Statistical analysis}

Generalized linear models (GLMs) were constructed to determine the occurrence of vertical stratification in arthropod guilds and the effect of petiole length on arthropod herbivores, predators, and borers (Crawley, 2002). The richness and abundance of herbivores, predators, and borers were used as response variables, whereas petiole length and vertical strata (attached, vegetation, and soil) were used as explanatory variables. All 138 petioles were used to construct stratification and resource availability models for borers, whereas 30 leaves were selected for herbivore and predator models to standardize the sampling effort in each stratum. The complete models were submitted to residual analysis to evaluate adequacy of error distribution (Crawley, 2007). All analyses were performed using R software (R Development Core Team, 2013).

\section{Results}

A total of 334 arthropods (136 herbivores and 198 predators) divided into 130 morphospecies (53 herbivore and 77 predator morphospecies) were sampled associated with dry leaves of C. pachystachya. The family Psyllidae was the most abundant among the herbivores with 27 morphospecies, whereas spiders were the most diverse arthropods among predators with 84 individuals and 32 morphospecies. In addition, 183 Coleoptera borers were sampled associated with the petiole. The subfamily Scolytinae was the most abundant with 182 individuals and eight morphospecies, whereas a single individual of the family Buprestidae was sampled.

There were no significant differences in richness and abundance of herbivores per leaf $(p>0.05)$ and borers per petiole $(p>0.05)$ between the strata. Conversely, the richness and abundance of predators were lower in leaves attached to the host plant (attached) and did not differ significantly between leaves in the vegetation and on the soil (Table 1; Figure 1). The richness and abundance of predators were not affected by petiole length $(\mathrm{p}>0.05)$. However, the richness and abundance of herbivores associated with leaves and bark beetles increased with petiole length (Table 1; Figures 2a-d).

\section{Discussion}

This is the first study to demonstrate with empirical results the effect of vertical stratification on the community structure of distinct arthropod feeding guilds associated with a specific microhabitat. In this study, we detected vertical stratification only in the guild of predator arthropods associated with dry leaves of C. pachystachya. The isolation of dry leaves attached to the plant relative to the surrounding vegetation likely creates greater difficulty for dispersal and colonization by non-winged arthropods, especially sessile groups and those living in nests or

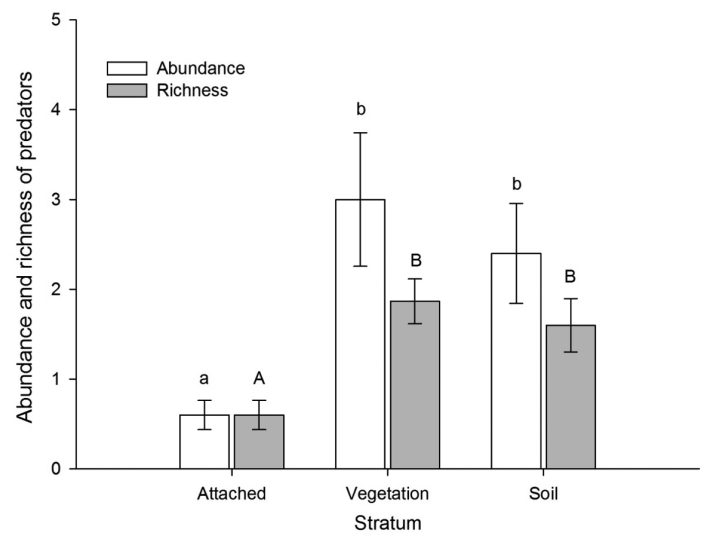

Figure 1. Richness and abundance (mean \pm standard error) of predators associated with dry leaves of Cecropia pachystachya along three vertical strata (attached, vegetation, and soil) in an area of Atlantic forest at Rio Doce State Park, Minas Gerais, Brazil. Different letters between bars indicate statistically significant difference $(p<0.05)$.

Table 1. Generalized linear models to the test for vertical stratification and the effect of dry leaf size on arthropod species; and the effect of petiole length on insect borers in Cecropia pachystachya in an area of Atlantic forest at Rio Doce State Park, Minas Gerais, Brazil. All models followed the quasipoisson error distribution.

\begin{tabular}{ccccccc}
\hline Response variable & Explanatory variable & d.f. & Deviance & $\begin{array}{c}\text { gl } \\
\text { residual }\end{array}$ & $\begin{array}{c}\text { Deviance } \\
\text { Residual }\end{array}$ & p value \\
\hline Abundance of & Stratum & 2 & 2.71 & 82 & 128.96 & 0.420 \\
herbivores & Petiole length & 1 & 56.74 & 83 & 186.62 & $<0.001$ \\
Richness of herbivores & Stratum & 2 & 9.76 & 82 & 233.6 & 0.287 \\
& Petiole length & 1 & 15.88 & 83 & 115.79 & 0.001 \\
Abundance of predators & Stratum & 2 & 48.83 & 82 & 230.87 & 0.001 \\
& Petiole length & 1 & 2.37 & 83 & 277.33 & 0.483 \\
Richness of predators & Stratum & 2 & 19.62 & 82 & 109.27 & $<0.001$ \\
& Petiole length & 1 & 0.67 & 83 & 128.22 & 0.495 \\
Abundance of bark & Stratum & 2 & 12.17 & 135 & 403.69 & 0.165 \\
beetles & Petiole length & 1 & 30.90 & 137 & 415.87 & 0.002 \\
Richness of bark beetles & Stratum & 2 & 34.38 & 135 & 122.08 & 0.106 \\
& Petiole length & 1 & 7.27 & 137 & 125.52 & 0.002 \\
\hline
\end{tabular}



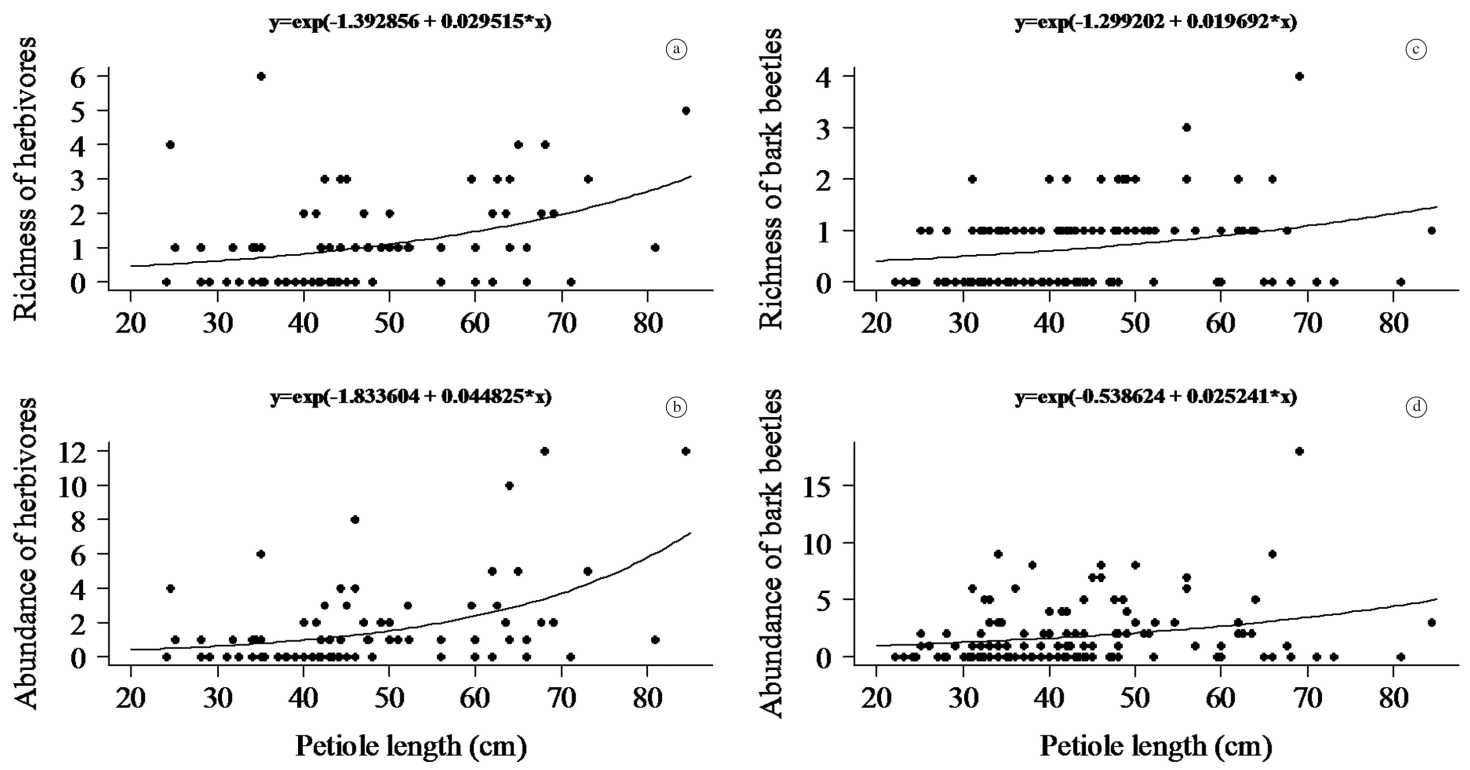

Figure 2. Effect of petiole length on richness (a) and abundance (b) of herbivore arthropods and richness (c) and abundance (d) of bark beetles in an area of Atlantic forest at Rio Doce State Park, Minas Gerais, Brazil. The curves were constructed using the generalized linear model parameters $(p<0.05$; Table 1$)$.

galleries such as spiders (Moran and Southwood, 1982; Stork, 1987). In fact, vegetation connectivity may act as a promoter of arthropod dispersal and has been used to explain the increase in richness and abundance of these organisms in tropical habitats invoke (Basset et al., 2003; Campos et al., 2006; Powell et al., 2011).

We observed that the herbivores richness and abundance remained similar between the studied strata, as well as for predators among vegetation and soil strata. Although our data were based only in dry leaves, our results corroborate studies done at larger scales, such as tree species and forest strata, indicating a probable relationship of cause and effect. Based on a comparative study about the guild composition of arthropod communities in trees, Moran and Southwood (1982) found a striking proportional constancy in the numbers of species in each guild among different tree species and between South Africa and Britain. Stork (1987) reported a similar result with canopy insects in Borneo. Similarly, our results showed that the structure of herbivore and predator guilds in dry leaves along the different vertical strata was highly similar. Our results are similar to those of Grimbacher and Stork (2007), who failed to find vertical stratification among most ground and canopy beetle feeding guilds. However, Stork and Grimbacher (2006), using the same dataset, checked the effect of vertical stratification on the composition of the beetle community. The contrasting results of vertical stratification at the species and feeding guild levels suggest an uniformity in resources between the studied strata, but also suggest that resource partitioning occurs at a finer scale (Grimbacher and Stork, 2007).

The richness and abundance of the herbivore guild increased with petiole length. The increased size of dry leaves determines the occurrence of a greater number and complexity of chambers where herbivores can find shelter against microclimate fluctuations and protection against natural enemies (Lawton, 1983; Bell et al., 1991). Predator-herbivore interactions should occur more frequently in less structurally complex leaves than more complex ones (Cuddington and Yodzis, 2002). In general, herbivores appear to respond positively to an increase in habitat size and structure regardless of the spatial scale investigated, which can range from small scales such as in this study to larger ones such as host plant size (Campos et al., 2006; Neves et al., 2013).

We expected that larger leaves had a greater number and complexity of chambers and supported a higher diversity of predators. Several studies have shown a positive relationship between the structural complexity of vegetation and diversity of predators (Halaj et al., 2000a, b; Klein et al., 2002; Ribas et al., 2003; Souza 2007; Sanders et al., 2008). Souza and Martins (2005) in a study using artificial branches concluded that the architecture of the branches is the most important factor that determines the abundance of spiders associated with plants. In addition, a recent meta-analysis showed that habitat structure plays an important role in determining the abundance of invertebrate generalist predators (Langellotto and Denno, 2004). Nevertheless, in this study we did not find a relationship between the richness and abundance of predators and leaf size. Riihimaki et al. (2006) found a negative effect of canopy structure on spider diversity and attributed this relationship to the foraging patterns of spiders. Moreover, the lack of relationship between leaf size and diversity of predators in our study may be related to the habitat scale used, i.e., dry leaves, which represent a small space to be colonized by these 
organisms. The competition between predators, especially spiders, for shelter against desiccation (Riechert and Tracy, 1975) or predators (Rosenberg, 1990), and foraging sites (Schmalhofer 2001; Romero and Vasconcellos-Neto, 2003) may also act at the scale investigated in our study, preventing the increase in species diversity in this guild.

As in our study, a high dominance of Scolytinae species has also been reported on the same system in Costa Rica (Jordal and Kirkendall, 1998). Insect borers, especially scolytids, feed and develop on recently cut or injured trees or nutritionally weakened plants (Wood, 1982). Thus, they significantly contribute to the maintenance and balance of the entire ecosystem, as they help recycle and eliminate dead or dying plants (Wood, 1982). In our study, petiole length positively influenced the richness and abundance of insect borers. Coulson (1979) suggested that borer survival is associated with trunk diameter, as larger plants provide more resources and protection against desiccation, climate variation, and natural enemies, and support a higher number of beetles. This guild seems to respond positively to plant architecture with respect to food and offspring development (Caraglio et al., 2001; Paulino Neto et al., 2005).

The different arthropod guilds are affected differently by the vertical stratification and resource availability, probably due to their biological requirements. Predators showed vertical stratification possibly due to the isolation of leaves in the attached stratum relative to the surrounding vegetation, but are not affected by petiole length. Herbivorous and borers insects were positively affected by petiole length, but not by vertical stratification. The increase in leaf size may increase the availability of shelter against predators and climate variations, for the herbivores, and larger petioles have greater availability of food and nesting sites for borers.

\section{Acknowledgements}

We would like to thank the Post Graduation Program in Ecology, Conservation and Wildlife Management (PPGECMVS) at UFMG for the opportunity to carry out this work during the Ecology Field Course/2012. To the State Forestry Institute of Minas Gerais, particularly to the administration of the Park in the person of Marcos Vinícius de Feitas, for all the physical structure and logistics available. To all the teachers and classmates for their suggestions and help in laboratory work. Finally, we are grateful to Luiz Eduardo M. Reis and Tadeu Guerra for reading and commenting on an earlier version of this manuscript.

\section{References}

BASSET, Y., ABERLENC, HP., BARRIOS, H., CURLETTI, G., BERENGER, JM., VESCO, JP., CAUSSE, P., HAUG, A., HENNION, AS., LESOBRE, L., MARQUES, F. and O'MEARA, R., 2001. Stratification and diel activity of arthropods in a lowland rainforest in Gabon. Biological Journal of the Linnean Society, vol.
72, no. 4, p. 585-607. http://dx.doi.org/10.1111/j.1095-8312.2001. tb01340.x.

BASSET, Y., ABERLENC, HP. and DELVARE, G., 1992. Abundance and stratification of foliage arthropods in a lowland rain forest of Cameroon. Ecological Entomology, vol. 17, no. 4, p. 310-318. http://dx.doi.org/10.1111/j.1365-2311.1992.tb01063.x.

BASSET, Y., NOVOTNY, V., BARRIOS, H., HOLLOWAY, JD. and MILLER, SE., 2003. Vertical stratification of arthropod assemblages. In BASSET, Y., NOVOTNY, V., MILLER, SE. and KITCHING, RL. (Eds.). Arthopods of tropical forests spatiotemporal dynamics and resource use in the canopy. Cambridge: Cambridge University Press. p. 17-29.

BELL, SS., MCCOY, ED. and MUSHINSKY, HR., 1991. Habitat structure - the physical arrangement of objects in space. London: Chapman and Hall. 428 p.

BREHM, G., 2007. Contrasting patterns of vertical stratification in two moth families in a Costa Rican lowland rain forest. Basic and Applied Ecology, vol. 8, no. 1, p. 44-54. http://dx.doi. org/10.1016/j.baae.2006.02.002.

BORROR, DJ., TRIPLEHORN, CA. and JOHNSON, NF., 2002. An introduction to the study of Insects. New York: Saunders College Publishing. 875 p.

CAMPOS, RI., VASCONCELOS, HL., RIBEIRO, SP., NEVES, FS. and SOARES, JP., 2006. Relationship between tree size and insect assemblages associated with Anadenanthera macrocarpa. Ecography, vol. 29, no. 3, p. 442-450. http://dx.doi.org/10.1111/ j.2006.0906-7590.04520.x.

CARAGLIO, Y., NICOLINI, E. and PETRONELLI, P., 2001. Observations on the links between the architecture of a tree (Dicorynia guianensis Amshoff) and Cerambycidae activity in French Guiana. Journal of Tropical Ecology, vol. 17, no. 3, p. 459-463. http://dx.doi.org/10.1017/S0266467401001316.

COULSON, RN., 1979. Population dynamics of bark beetles. Annual Review of Entomology, vol. 24, no. 1, p. 417-447. http:// dx.doi.org/10.1146/annurev.en.24.010179.002221.

CUDDINGTON, K. and YODZIS, P., 2002. Predator-prey dynamics and movement in fractal environments. American Naturalist, vol. 160, no. 1, p. 119-134. http://dx.doi.org/10.1086/340611. PMid:18707503.

CRAWLEY, MJ., 2002. Statistical computing-an introduction to data analysis using splus. London: John Wiley and Sons. 772 p.

CRAWLEY, MJ., 2007. The R book. London: Jhon Willey and Sons. $1076 \mathrm{p}$.

DAVIS, AJ., SUTTON, SL. and BRENDELL, MJD., 2011. Vertical distribution of beetles in a tropical rainforest in Sulawesi: the role of the canopy in contributing to biodiversity. Sepilok Bulletin, vol. $13-14$, p. 59-83.

DEVRIES, PJ., WALLA, T. and GREENEY, HF., 1999. Species diversity in spatial and temporal dimensions of fruit-feeding butterflies from two Ecuadorian rainforests. Biological Journal of the Linnean Society, vol. 68, no. 3, p. 333-353. http://dx.doi. org/10.1111/j.1095-8312.1999.tb01175.x.

ESPÍRITO-SANTO, MM., NEVES, FS., ANDRADE-NETO, FR. and FERNANDES, GW., 2007. Plant architecture and meristem dynamics as the mechanisms determining the diversity of gallinducing insects. Oecologia, vol. 153, no. 2, p. 353-364. http:// dx.doi.org/10.1007/s00442-007-0737-8. PMid:17453251. 
FEIO, RN., WIEDERHECKER, H., BRAGA, UML. and SANTOS, PS., 1998. Anfibios do Parque Estadual do Rio Doce (Minas Gerais). Viçosa: Universidade Federal de Viçosa/ Instituto Estadual de Florestas/ Imprensa Universitária. 32 p.

GODFRAY, HCJ. and LAWTON, JH., 2001. Scale and species numbers. Trends in Ecology \& Evolution, vol. 16, no. 7, p. 400-404. http://dx.doi.org/10.1016/S0169-5347(01)02150-4. PMid:11403873.

GRIMBACHER, PS. and STORK, NE., 2007. Vertical stratification of feedig guilds body size in beetle assemblages from an Australian tropical rainforest. Austral Ecology, vol. 32, no. 1, p. 77-85. http:// dx.doi.org/10.1111/j.1442-9993.2007.01735.x.

HALAJ, J., CADY, AB. and UETZ, GW., 2000a. Modular habitat refugia enhance generalist predators and lower plant damage in soybeans. Environmental Entomology, vol. 29, no. 2, p. 383-393. http://dx.doi.org/10.1093/ee/29.2.383.

HALAJ, J., ROSS, DW. and MOLDENKE, AR., 2000b. Importance of habitat structure to the arthropod food-web in Douglas-fir canopies. Oikos, vol. 90, no. 1, p. 139-152. http:// dx.doi.org/10.1034/j.1600-0706.2000.900114.x.

HEISSWOLF, A., OBERMAIER, E. and POETHKE, HJ., 2005. Selection of large host plants for oviposition by a monophagous leaf beetle: nutritional quality or enemy-free space? Ecological Entomology, vol. 30, no. 3, p. 299-306. http://dx.doi.org/10.1111/ j.0307-6946.2005.00706.x.

Instituto Estadual de Florestas - IEF, 2012. Parque Estadual do Rio Doce. IEF. Available from: <http://www.ief.mg.gov.br/ component/content/195?task=view>. Access in: 23 July 2013.

JEFFRIES, MJ. and LAWTON, JH., 1984. Enemy free space and the structure of ecological communities. Biological Journal of the Linnean Society, vol. 23, no. 4, p. 269-286. http://dx.doi. org/10.1111/j.1095-8312.1984.tb00145.x.

JORDAL, BH. and KIRKENDALL, LR., 1998. Ecological relationships of a guild of tropical beetles breeding in Cecropia leafstalks in Costa Rica. Journal of Tropical Ecology, vol. 14, no. 2, p. 153-176. http://dx.doi.org/10.1017/S0266467498000133.

KLEIN, A., STEFFAN-DEWENTER, I. and TSCHARNTKE, T., 2002. Predator-prey ratios on cocoa along a land-use gradient in Indonesia. Biodiversity and Conservation, vol. 11, no. 4, p. 683-693. http://dx.doi.org/10.1023/A:1015548426672.

LANGELLOTTO, GA. and DENNO, RF., 2004. Responses of invertebrate natural enemies to complex-structured habitats: a meta-analytical synthesis. Oecologia, vol. 139, no. 1, p. 1-10. http://dx.doi.org/10.1007/s00442-004-1497-3. PMid:14872336.

LAWTON, J., 1983. Plant architecture and the diversity of phytophagous insects. Annual Review of Entomology, vol. 28, no. 1, p. 23-39. http://dx.doi.org/10.1146/annurev.en.28.010183.000323.

LONGINO, JT. and NADKARNI, NM., 1990. A comparison of ground and canopy leaf litter ants (Hymenoptera: Formicidae) in a neotropical montane forest. Psyche, vol. 97, no. 1-2, p. 81-93. http://dx.doi.org/10.1155/1990/36505.

MORAN, VC. and SOUTHWOOD, TRE., 1982. The guild composition of arthropod communities in trees. Journal of Animal Ecology, vol. 51, no. 1, p. 289-306. http://dx.doi.org/10.2307/4325.

NEVES, FS., SPERBER, CF., CAMPOS, RI., SOARES, JP. and RIBEIRO, SP., 2013. Contrasting effects of sampling scale on insect herbivores distribution in response to canopy structure.
Revista de Biologia Tropical, vol. 61, no. 1, p. 125-137. http:// dx.doi.org/10.15517/rbt.v61i1.10894. PMid:23894967.

OBERMAIER, E., HEISSWOLF, A., POETHKE, HJ., RANDLKOFER, B. and MEINERS, T., 2008. Plant architecture and vegetation structure: two ways for insect herbivores to escape parasitism. European Journal of Entomology, vol. 105, no. 2, p. 233-240. http://dx.doi.org/10.14411/eje.2008.033.

PAULINO NETO, HF., ROMERO, GQ. and VASCONCELLOS NETO, J., 2005. Interactions between Oncideres humeralis Thomson (Coleoptera: Cerambycidae) and Melastomataceae: host-plant selection and patterns of host use in south-east Brazil. Neotropical Entomology, vol. 34, no. 1, p. 7-14. http://dx.doi. org/10.1590/S1519-566X2005000100002.

POWELL, S., COSTA, AN., LOPES, CT. and VASCONCELOS, HL., 2011. Canopy connectivity and the availability of diverse nesting resources affect species coexistence in arboreal ants. Journal of Animal Ecology, vol. 80, no. 2, p. 352-360. http:// dx.doi.org/10.1111/j.1365-2656.2010.01779.x. PMid:21118199.

PRICE, PW., BOUTON, CE., GROSS, P., MCPHERON, BA., THOMPSON, JN. and WEIS, AE., 1980. Interaction among three trophic levels: influence of plants on interactions between insect herbivores and natural enemies. Annual Review of Ecology and Systematics, vol. 11, no. 1, p. 41-65. http://dx.doi.org/10.1146/ annurev.es.11.110180.000353.

R Development Core Team, 2013. R: a language and environment for statistical computing. Vienna: R Foundation for Statistical Computing. Version 2.13. Available from: $<$ http://www.r-project. org>. Access in: 30 Apr. 2013.

RIBAS, CR., SCHOEREDER, JH., PIC, M. and SOARES, SM., 2003. Tree heterogeneity, resource availability, and larger scale processes regulating arboreal ant species richness. Austral Ecology, vol. 28 , no. 3 , p. $305-314$. http://dx.doi.org/10.1046/j.14429993.2003.01290.x

RIECHERT, SE. and TRACY, CR., 1975. Thermal balance and prey availability: bases for a model relating web-site characteristics to spider reproductive success. Ecology, vol. 56, no. 2, p. 265-284. http://dx.doi.org/10.2307/1934960.

RIIHIMÄKI, J., KAITANIEMI, P., KORICHEVA, J. and VEHVILÄINEN, H., 2005. Testing the enemies hypothesis in forest stands: the important role of tree species composition. Oecologia, vol. 142, no. 1, p. 90-97. http://dx.doi.org/10.1007/ s00442-004-1696-y. PMid:15322903.

RIIHIMÄKI, J., VEHVILÄINEN, H., KAITANIEMI, P. and KORICHEVA, J., 2006. Host tree architecture mediates the effect of predators on herbivore survival. Ecological Entomology, vol. 31 , no. 3, p. 227-235. http://dx.doi.org/10.1111/j.13652311.2006.00784.x

ROMANIUC NETO, S., GAGLIOTI, AL. and GUIDO, BMO., 2009. Urticaceae Juss. do Parque Estadual das Fontes do Ipiranga, São Paulo, SP, Brasil. Hoehnea, vol. 36, no. 1, p. 193-205. http:// dx.doi.org/10.1590/S2236-89062009000100012.

ROMERO, GQ. and VASCONCELLOS-NETO, J., 2003. Natural history of Misumenops argenteus (Thomisidae): seasonality and diet on Trichogoniopsis adenantha (Asteraceae). The Journal of Arachnology, vol. 31, no. 2, p. 297-304. http://dx.doi. org/10.1636/02-19.

ROSENBERG, KV., 1990. Dead-leaf foraging specialization in tropical forest birds: measuring resource availability and use. In MORRISON, ML., RALPH, CJ., VERNER, J. and JEHL, JR. 
(Eds.). Avian foraging: theory, methodology, and applications. California: Cooper Ornithological Society. p. 360-368. Studies in Avian Biology, no. 13.

SANDERS, D., NICKEL, H., GRUTZNER, T. and PLATNER, C., 2008. Habitat structure mediates top-down effects of spiders and ants on herbivores. Basic and Applied Ecology, vol. 9, no. 2, p. 152-160. http://dx.doi.org/10.1016/j.baae.2007.01.003.

SERVAT, GP., 1995. Availability and use of food resources by two species of Automolus (Aves, Furmariidae). Saint Louis: University of Missouri. 90 p. PhD Thesis.

SCHMALHOFER, VR., 2001. Tritrophic interactions in a pollination system: impacts of species composition and size of flower patches on the hunting success of a flower-dwelling spider. Oecologia, vol. 129, no. 2, p. 292-303. http://dx.doi.org/10.1007/ s004420100726.

SCHROEDER, B., BUDDLE, CM. and SAINT-GERMAIN, M., 2009. Activity of flying beetles (Coleoptera) at two heights in canopy gaps and intact forests in a Hardwood Forest in Quebec. Canadian Entomologist, vol. 141, no. 5, p. 515-520. http://dx.doi. org/10.4039/n09-022.

SOUZA, ALT., 2007. Influência da estrutura do habitat na abundância e diversidade de aranhas. In GONZAGA, MO., SANTOS, A. and JAPYSSÚ, HF. (Eds.). Ecologia e comportamento de aranhas. Rio de Janeiro: Editora Interciência. p. 25-43.

SOUZA, ALT. and MARTINS, RP., 2005. Foliage density of branches and distribution of plant-dwelling spiders. Biotropica, vol. 37 , no. 3, p. 416-420. http://dx.doi.org/10.1111/j.17447429.2005.00055.x.

SPERBER, C., NAKAYAMA, K., VALVERDE, MJ. and NEVES, FS., 2004. Tree species richness and density affect parasitoid diversity in cacao agroforestry. Basic and Applied Ecology, vol. 5, no. 3, p. 241-251. http://dx.doi.org/10.1016/j.baae.2004.04.001.

STORCH, D. and GASTON, KJ., 2004. Untangling ecological complexity on different scales of space and time. Basic and Applied Ecology, vol. 5, no. 5, p. 389-400. http://dx.doi.org/10.1016/j. baae.2004.08.001.

STORK, NE., 1987. Arthropod faunal similarity of Bornean rain forest trees. Ecological Entomology, vol. 12, no. 2, p. 219-226. http://dx.doi.org/10.1111/j.1365-2311.1987.tb01000.x.

STORK, NE. and GRIMBACHER, PS., 2006. Beetle assemblages from an Australian tropical rainforest show that the canopy and the ground strata contribute equally to biodiversity. Proceedings. Biological Sciences, vol. 273, no. 1596, p. 1969-1975. http:// dx.doi.org/10.1098/rspb.2006.3521. PMid:16822759.

STRONG, DR., LAWTON, JH. and SOUTHWOOD, TRE., 1984. Insects on plants. Community patterns and mechanisms. Cambridge: Harvard University Press. 313 p.

VEHVILÄINEN, H., KORICHEVA, J. and RUOHOMAKI, K., 2008. Effects of stand tree species composition and diversity on abundance of predatory arthropods. Oikos, vol. 117, no. 6, p. 935-943. http://dx.doi.org/10.1111/j.0030-1299.2008.15972.x.

WENG, J., NISHIDA, K., HANSON, P. and LAPIERRE, L., 2007. Biology of Lissoderes Champion (Coleoptera, Curculionidae) in Cecropia saplings inhabited by Azteca Ants. Journal of Natural History, vol. 41, no. 25-28, p. 1679-1695. http://dx.doi. org/10.1080/00222930701466575.

WOOD, SL., 1982. The bark and Ambrosia beetles of North and Central America (Coleoptera: Scolytidae), a taxonomic monograph. Great Basin Naturalist Memoirs, vol. 6, p. 1-1360. 